\author{
(c) (1) () \\ Jurnal Pendidikan Dasar Indonesia is licensed under \\ A Creative Commons Attribution-Non Commercial 4.0 International License
}

\title{
Media Musik dan lagu Pada Proses Pembelajaran
}

\author{
Ainoer Roffiq ${ }^{1)}$, Ikhwanul Qiram ${ }^{2)}$, Gatut Rubiono ${ }^{3)}$ \\ 1) Universitas PGRI Banyuwangi, Jawa Timur \\ E-mail: roffiq@uniba-bwi.ac.id \\ 2) Universitas PGRI Banyuwangi, Jawa Timur \\ 3) Universitas PGRI Banyuwangi, Jawa Timur
}

\begin{abstract}
Abstrak. Suasana lingkungan belajar dalam kelas sangat penting dan berpengaruh terhadap hasil belajar siswa. Suasana lingkungan belajar ini diwujudkan dalam bentuk pengkondisian ruang kelas pembelajaran. Pengkondisian ini menyangkut kondisi fisik bangunan dan juga kenyamanan tempat duduk siswa. Kecukupan cahaya atau penerangan juga diperlukan. Selain itu, hal ini juga dapat dilakukan dengan memberikan kenyamanan tambahan yang salah satunya dapat digunakan yaitu memberikan musik. Hasil-hasil penelitian terdahulu menyatakan bahwa musik bermanfaat bagi ibu hamil dan berpengaruh terhadap janin yang dikandung. Musik dapat mempengaruhi detak jantung pendengarnya. Musik juga dapat menenangkan pikiran seseorang dan menjadi alat bantu bagi pengembangan kecerdasan manusia. Salah satu jenis musik yang banyak dipakai dalam pengkondisian suasana belajar atau suasana kerja adalah jenis musik klasik. Hasil-hasil penelitian tindakan kelas menyatakan bahwa musik berpengaruh terhadap proses pembelajaran siswa dalam kelas.
\end{abstract}

Kata Kunci: musik, lagu, media, suasana belajar, pembelajaran

\section{Pendahuluan}

Proses pembelajaran di kelas berkaitan erat dengan kompetensi guru, siswa, kurikulum, beserta sarana dan prasarana pendukungnya. Guru mempunyai tugas untuk memilih model pembelajaran yang tepat dan sesuai dengan materi yang akan dipelajari. Belajar itu sendiri pada dasarnya merupakan suatu proses perubahan melalui kegiatan dan latihan baik di dalam laboratorium maupun dalam lingkungan alamiah (Ekayana AAG, et al, 2013). Suasana lingkungan belajar dalam kelas sangat penting dan berpengaruh terhadap hasil belajar siswa (Ashari A, et al, 2014). Untuk itu pengkondisian lingkungan belajar sangat diperlukan. Hal ini juga berlaku bagi suasana lingkungan di dalam kelas karena mayoritas kegiatan belajar siswa dilakukan di dalam kelas.

Pengkondisian ruang kelas dapat dilakukan dengan berbagai cara. Selain menyangkut kondisi fisik bangunan juga kenyamanan tempat duduk siswa. Kecukupan cahaya atau penerangan juga diperlukan. Selain itu, hal ini juga dapat dilakukan dengan memberikan kenyamanan tambahan yang salah satunya dapat digunakan yaitu memberikan musik. Penelitian manfaat musik bagi manusia telah banyak dilakukan. Bagi ibu yang sedang hamil, lagu-lagu klasik dapat membebaskan dari stress akibat kehamilan. Kondisi emosi seorang ibu hamil sangat mempengaruhi perkembangan janin yang dikandungnya. Musik juga berpengaruh terhadap kecerdasan emosional para remaja (Mubarok S, 2013).

Faktor lingkungan dapat berupa suara di sekitar. Siswa dapat menerima pelajaran dengan baik apabila tidak ada suara-suara berisik atau yang mengganggu. Siswa akan terganggu apabila terdengar suara-suara berisik sehingga merasa tidak nyaman di kelas dan dapat mempengaruhi timbulnya kecemasan pada siswa. Ada pula suara yang dapat meningkatkan belajar siswa, seperti musik yang dapat mempengaruhi kinerja otak dan musik yang menenangkan. Suara yang menenangkan dan atau mempengaruhi kinerja otak dapat mencegah kesulitan belajarakibat kecemasan dalam proses pembelajaran (Susanti DW, Rohmah FA, 2011).

Salah satu yang dapat mempengaruhi motivasi belajar adalah minat pada musik. Memang tidak dapat dibantah lagi bahwa musik telah memberikan dampak yang sangat luas terhadap masyarakat. Musik tidak hanya memberikan hiburan semata terhadap para pendengarnya, namun juga dapat menjadi sarana untuk menyampaikan pesan moral, kritik terhadap pemerintah, mengungkapkan perasaan, dan mendorong atau memotivasi seseorang untuk melakukan sesuatu baik yang positif maupun negatif. Oleh karena itu, musik tidak dapat dianggap sebagai sesuatu yang 
dikesampingkan dalam proses pembentukan sebuah karakter seseorang (Marchita Y, 2013).

Musik merupakan suatu kebutuhan pokok bagi setiap manusia, karena musik dapat menjadikan orang merasa senang, gembira dan nyaman. Musik bisa menjadi efektif di bidang akademis dengan membantu pembentukan pola belajar, mengatasi kebosanan dan menangkal kebisingan eksternal yang mengganggu. Membuat musik secara aktif berpengaruh pada perkembangan mental dan fisiologis otak. Kegiatan ini membantu pembentukan jalur-jalur saraf yang berhubungan dalam otak dan dengan cara mendorong terbentuknya hubungan antarsel otak. Hal ini dapat meningkatkan pertumbuhan mental dan fisik seseorang. Musik juga dapat membantu kita merasa bertenaga, percaya diri, mengurangi kesedihan, menghapus kemarahan, melepaskan stres serta mengurangi rasa takut dan cemas (Rismi U, 2012).

Media ilustrasi musik dapat mengubah lingkungan belajar menjadi menyenangkan sehingga para siswa pun antusias untuk belajar. Musik dapat memicu keterkaitan besar di antara bidang-bidang di dalam otak yang bertanggung jawab atas emosi dan ingatan. Menggunakan musik sebagai alat memaksimalkan potensi manusia merupakan upaya yang sangat berarti. Musik mampu memotivasi dan mendorong partisipasi dalam kegiatan yang akan membantu meraih tujuan dalam fungsifungsi sosial, bahasa, dan motorik. Dengan menggunakan media ilustrasi musik di sekolah diharapkan mampu meningkatkan kemampuan menulis puisi siswa dan mampu mengubah suasana lingkungan belajar siswa menjadi menyenangkan (Wulandini IF, 2011).

Musik dapat mempengaruhi detak jantung pendengarnya. Musik juga dapat menenangkan pikiran seserang dan menjadi alat bantu bagi pengembangan kecerdasan manusia. Aplikasi musik dalam beribadah diyakini dapat menambah kualitas ibadah tersebut. Sehingga dalam hal ini, musik berpengaruh terhadap otak dan emosi manusia (Salim D, 2010). Salah satu jenis musik yang banyak dipakai dalam pengkondisian suasana belajar atau suasana kerja adalah jenis musik klasik. Musik klasik dikenal dengan tempo lambat dan dapat ditemukan dalam semua genre musik yang dapat memberikan ketenangan dan kedamaian adalah musik dengan tempo yang lebih lambat (Susanti DW, Rohmah FA, 2011).

Biasanya, para terapis membagi tema musik ke dalam lima jenis, yaitu musik bertema trance, melow, semangat, ceria, dan relaksasi. Musik bertema trance adalah jenis musik yang mengandung ungkapan rasa ceria yang luar biasa. Jenis musik semacam itu cocok untuk menyembuhkan orang yang mengalami tekanan mental atau stress. Musik yang berirama melow dan melankolis merupakan jenis musik yang menyayat perasaan. Musik semacam itu bisa menurunkan asupan sejumlah komposisi kimia dalam otak. Musik bertema melankolis dalam kondisi normal bisa mengurangi rasa sakit dan nyeri. Sementara jika didengar di saat sedih, bisa mempermudah bagi seseorang untuk menahan rasa duka. Namun, penggunaan musik bertema seperti itu secara berlebihan bisa menurunkan semangat dan kebencian. Musik bertema semangat merupakan jenis musik yang bisa membangkitkan reaksi kuat dan cepat yang disertai dengan tanggapan fisiologis (Anwar S, 2013).

\section{Pembahasan}

\section{A. Penelitian Terdahulu}

Salim D, 2010 meneliti ini meneliti pengaruh musik terhadap konsentrasi belajar siswa kelas 2 SMUK 1 Salatiga. Jumlah sampling sebanyak 29 siswa. Mata pelajaran yang diteliti adalah Matematika dan Bahasa Inggris. Jenis musik yang digunakan adalah musik degung Sunda dan musik heavy metal. Selain itu juga dilakukan perbandingan tanpa musik latar. Hasil penelitian menunjukkan bahwa musik latar yang digunakan berpengaruh terhadap konsentrasi belajar siswa kelas 2 SMUK 1 Salatiga. Musik degung Sunda berpengaruh positip terhadap mata pelajaran Bahasa Inggris dan negatip terhadap Matematika. Sedangkan musik heavy metal berpengaruh secara negatip terhadap kedua mata pelajaran.

Susanti DW, Rohmah FA, 2011 meneliti efektivitas musik klasik dalam menurunkan kecemasan matematika (math anxiety) pada siswa kelas XI. Penelitian ini bertujuan untuk mengetahui efektivitas musik klasik dalam menurunkan kecemasan matematika. Subyek dalam penelitian ini menggunakan siswa SMA Negeri 5 Yogyakarta kelas XI jurusan Ilmu Pengetahuan Sosial (IPS) yang memiliki skor IQ rata-rata dan di atas rata-rata serta tingkat kecemasan tinggi dan sangat tinggi yang berjumlah 14 orang. Pengumpulan data menggunakan Skala Kecemasan Matematika dan Lembar Evaluasi Musik. Penelitian ini menggunakan rancangan eksperimen pre testpost test control group design. Random yang digunakan adalah sistem matching. Analisis data dalam penelitian ini menggunakan analisis uji Wilcoxon. Hasil analisis data menunjukkan ada penurunan skor yang signifikan antara pretest dan posttestpada kelompok eksperimen (KE) dengan $\mathrm{p}=0,014$ yang mengindikasikan musik klasik efektif dalam menurunkan kecemasan matematika pada siswa. Kecemasan matematika dapat menurun seiring siswa mendengarkan musik klasik sambil belajar matematika.

Fika A, 2012 meneliti pengaruh musik dan inteligensi visual spasial terhadap hasil belajar matematika siswa kelas V kompleks SD jalan Halat Medan. Tujuan penelitian ini untuk mengetahui: (1) Hasil belajar Matematika siswa yang menggunakan musik pop lebih tinggi dari pada hasil belajar Matematika siswa yang mengutamakan musik klasik dan tanpa musik, (2) Hasil belajar Matematika siswa yang memiliki inteligensi visual-spasial balk lebih tinggi daripada basil belajar Matematika siswa yang memiliki inteligensi visual-spasial sedang dan cukup, (3) Interaksi antara musik dan inteligensi visual-spasial dalam memberikan pengaruh terhadap basil belajar Matematika siswa. Penelitian ini merupakan penelitian quasi eksperimen yang dilaksanakan di kelas V Komplek SD Jalan Halat Medan. Populasi dalam penelitian ini terdiri 
270 orang siswa, sampel penelitian ditetapkan dengan menggunakan cluster random sampling, sehingga terpilih SD Negeri 060809 menjadi kelas yang menggunakan musik pop, SD Negeri 060810 menjadi kelas yang menggunakan musik klasik, dan SD Negeri 060807 menjadi kelas yang belajar tanpa menggunakan musik.

Tes psikologi diberikan kepada siswa untuk mengklasifikasikan kemampuan inteligensi visual-spasial dengan kategori baik, sedang dan cukup. Untuk tes inteligensi visual-spasial digunakan tes psikologi yaitu tes ENS, guna menguji hipotesis hasil belajar Matematika siswa yang memiliki inteligensi visual spasial baik, sedang dan cukup. Uji statistik yang digunakan adalah statistik deskriptif untuk menyajikan data dan statistik inferensial menggunakan ANOVA 3 jalur. Sebelum ANOVA 3 jalur digunakan terlebih dahulu dilakukan uji analisis data yaitu uji normalitas dan uji homogenitas. Instrumen yang digunakan untuk hasil belajar Matematika adalah pilihan ganda yang berjumlah 40 butir soal dimana reliabilitas tes didapat sebesar 0.938. Hasil pengujian menunjukkan bahwa siswa yang belajar sambil mendengarkan musik pop memiliki hasil belajar Matematika yang lebih tinggi dibanding dengan siswa yang menggunakan musik klasik dan tanpa musik. Ini ditunjukkan dari nilai Fhitung $=20.59$ $>$ Ftabel 4;126) $=2.44$ pada taraf signifikan a sebesar 0.05 . Siswa yang memiliki intelgensi visual spasial baik akan memperoleh hasil belajar mata pelajaran Matematika lebih tinggi dibanding siswa yang memiliki inteligensi visualspacial sedang dan wimp. Ini ditunjukkan dari Fhitung = $183.59>$ Ftabel $(4 ; 126)=2.44$ pada taraf signifikan $\mathrm{a}=$ 0.05. Terdapat interaksi antara musik dan inteligensi visual-spasial terhadap hasil belajar Matematika. Ini ditunjukkan dari hasil Fhitung $=11.86>$ Ftabel $(4 ; 126)=$ 2.44 pada taraf signifikan $\mathrm{a}=0.05$. Hipotesis telah menunjukkan bahwa siswa yang menggunakan musik pop dalam pembelajaran akan mendapatkan basil belajar lebih tinggi dibanding dengan siswa yang menggunakan musik klasik dan tanpa musik dalam pembelajaran.

Siswa yang memiliki inteligensi visual-spasial baik akan memberikan hasil belajar yang lebih tinggi dibanding dengan siswa yang memiliki inteligensi visual-spasial sedang dan cukup. Siswa yang memiliki inteligensi visualspasial baik dan sedang akan memperoleh basil belajar Matematika lebih tinggi jika dalam pembelajarannya menggunakan musik pop dan siswa yang memiliki inteligensi visual-spasial cukup akan memperoleh hasil belajar Matematika lebih tinggi jika dalam pembelajarannya menggunakan musik klasik.

Kurniawati LD, et al, 2013 meneliti pengaruh musik klasik karya WA Mozart terhadap kecerdasan emosional kelas 5 SDN 06 Pontianak. Latar belakang penelitian ini adalah adanya kesulitan peserta didik berkonsentrasi dalam pelajaran dan kurang bersemangat. Hal tersebut menyebabkan timbulnya gejala psikis, yang berakibat pada proses belajar mengajar menjadi tidak maksimal. Penggunaan musik dalam belajar diharapkan dapat menjawab fenomena yang terjadi pada peserta didik.
Metode yang digunakan dalam penelitian ini adalah preexperimental design dengan model rancangan penelitian pre-test dan post-test group. Populasi penelitian adalah siswa kelas 5 SDN 06 Pontianak yang terdiri dari kelas 5A, 5B, 5C. Dengan menggunakan teknik random sampling (diambil secara acak), penulis memperoleh sampel sebanyak 26 orang siswa. Hasil penelitian ini menunjukkan bahwa pengaruh musik klasik karya Mozart terhadap kecerdasan emosional kelas 5 SDN 06 Pontianak mengalami peningkatan yang signifikan yaitu thitung > ttabel $(7,67>1,708)$ dengan effect size 4,752 dalam kategori tinggi dan hasil pre-test sebesar 26,34 dan post-test sebesar 65,34 .

Yogasara T et al, 2014 meneliti pengaruh jenis musik dan aromaterapi terhadap kemampuan kognitif mahasiswa untuk tiap tipe kepribadian. Kombinasi jenis musik dan aromaterapi hanya berpengaruh terhadap kemampuan kognitif mahasiswa yang memiliki IPK $<2,75$, namun tidak berpengaruh terhadap mahasiswa secara umum. Kombinasi musik dan aromaterapi yang tepat untuk kemampuan kognitif berhitung responden IPK $<2,75$ adalah aromaterapi peppermint dan musik rock. Kemampuan menghitung dan menghapal seseorang tidak dipengaruhi oleh jenis aromaterapi ataupun jenis musik, akan tetapi dipengaruhi oleh kepribadiannya. Orang berkepribadian koleris cenderung lebih mudah menghitung, dibandingkan yang lainnya. Orang berkepribadian melankolis lebih mudah menghapal dibandingkan orang berkepribadian lainnya.

\section{B. Suasana Belajar Siswa}

Pendidikan di sekolah tidak dapat dilepaskan dari proses pembelajaran dan interaksi antara guru dan siswa. Pembelajaran merupakan suatu proses yang rumit karena siswa tidak sekedar menyerap informasi dari guru, tetapi juga melibatkan berbagai kegiatan dan tindakan yang harus dilakukan untuk mencapai hasil belajar yang baik. Guru merupakan kunci dalam meningkatkan mutu pendidikan dan berada di titik sentral dari setiap usaha reformasi pendidikan yang diarahkan pada perubahan. Guru bertanggung jawab untuk mengatur, mengarahkan, dan menciptakan suasana yang mendorong siswa untuk melaksanakan kegiatan-kegiatan di kelas (Puspitasari DB, 2012).

Salah satu faktor yang dapat mendorong atau menghalangi motivasi belajar siswa adalah iklim kelas. Iklim kelas yang dirasakan aman oleh siswa akan mendukung siswa dalam melakukan aktivitas belajar. Namun iklim yang terbentuk dalam kelas juga dapat dirasakan mengancam oleh siswa dan berakibat pada rendahnya keterlibatan siswa dalam belajar. Iklim kelas memiliki peran penting dalam menciptakan suatu lingkungan yang dapat meningkatkan motivasi belajar dan prestasi siswa. Iklim kelas yang mendukung siswa dalam belajar akan membuat siswa merasa aman, bebas dalam menyampaikan ide-ide yang dimiliki, serta mempunyai kualitas yang baik dalam kelas, seperti saling memberikan 
perhatian dan saling menghargai sehingga akan membuat siswa lebih terdorong untuk belajar (Puspitasari DB, 2012).

Tujuan pendidikan adalah membentuk sumberdaya manusia yang berkualitas tinggi yaitu manusia yang mampu menghadapi perkembangan zaman. Guna mencapai tujuan tersebut diperlukan proses pendidikan. Keberhasilan suatu pendidikan salah satunya ditientukan bagaimana proses belajar mengajar berlangsung. Selain itu interaksi belajar pada prinsipnya tergantung pada guru dan siswa. Guru dituntut untuk menciptakan suasana belajar yang efektif, sedangkan siswa dituntut adanya semangat dan dorongan untuk aktif dalam proses belajar mengajar, sehingga keberhasilan belajar dalam bidang kognitif, afektif dan psikomotorik dapat tercapai (Sabil H, Winarni S, 2013).

\section{Pengaruh Musik}

Musik merupakan salah satu hal yang mempunyai pengaruh pada kehidupan manusia, mulai dari bayi hingga seseorang menjadi dewasa. Hal ini telah diteliti oleh para ilmuwan. Penelitian membuktikan bahwa musik, terutama musik klasik sangat mempengaruhi perkembangan IQ (Intelegent Quotien) dan EQ (Emotional Quotien). Seorang anak yang sejak kecil terbiasa mendengarkan musik akan lebih berkembang kecerdasan emosional dan intelegensinya dibandingkan dengan anak yang jarang mendengarkan musik. Yang dimaksud musik di sini adalah musik yang memiliki irama teratur dan nada-nada yang teratur, bukan nada-nada "miring". Tingkat kedisiplinan anak yang sering mendengarkan musik juga lebih baik dibanding dengan anak yang jarang mendengarkan musik.

Paparan musik juga dikaitkan dengan perubahan emosi pendengarnya. Musik merupakan stimulus universal yang sangat berpotensi menginduksi suasana hati. Dari sisi pandang ilmu syaraf kognitif (cognitive neuroscience), emosi memiliki komponen-komponen. Dalam hal ini terdapat perbedaan yang sangat mendasar antara mengalami emosi secara sadar (merasakan), mengekspresikannya dan mengenalinya sebagai pengetahuan. Respon emosional bisa terjadi tanpa harus didahului proses mengalami emosi secara sadar. Artinya, respon bisa muncul tanpa perlu didahului adanya rasa. Mendengarkan musik merupakan salah satu kejadian dimana respon emosional bisa muncul tanpa perlu didahului adanya perasaan emosi. Area-area otak yang terlibat dalam pembentukan komponen-komponen respon emosional adalah hipotalamus dan nuklei batang otak terlibat dalam kontrol otonom eferen, amigdala dan korteks prefrontal ventromedial terlibat dalam kontrol otonom tingkat tinggi, sementara insula dan korteks yang terkait dengan somato sensor kanan berperan pada pengalaman sadar emosional (Tsuchiya N, Adolphs R).

Pengaruh musik terhadap kecerdasan otak seseorang yaitu membuat nouron baru akna menjadi sirkuit jika terdapat rangsang musik, sehingga neuron yang terpisahpisah itu bertautan dan mengintegrasikan diri dalam sirkuit otak, sehingga terjadi perpautan antara neuron otak kanan dan kiri itu. Manfaat musik bagi kecerdasan otak yaitu musik dapat memberikan rangsangan-rangsangan yang kaya untuk segala aspek perkembangan secara kognitif dan kecerdasan emosional. Bahaya atau efek samping dari terapi musik ini yaitu jika seseorang terlalu sering mendengarkan musik dengan volume yang keras maka dapat menggangku sistem kerja syaraf pendengaran. Jenis aliran musik yang cocok untuk terapi kecerdasan otak yaitu musik yang memiliki irama yang tertur dan nada-nada yang teratur, akan lebih baik memilih lagu yang lembut. Tingkat keefektifan penggunaan terapi musik terhadap kecerdasan otak seseorang yaitu sebesar 70\% (Prajnamita, 2010).

Penerapan musik dapat meningkatkan aktivitas siswa terhadap pembelajaran matematika. Tindakan kelas yang dilakukan sebanyak 3 kali putaran pada siswa kelas VIIIC SMP Negeri 1 Sambi menunjukkan bahwa metode ini layak untuk meningkatkan aktivitas siswa terhadap pembelajaran matematika. Ada peningkatan aktivitas siswa terhadap pembelajaran matematika dilihat dari beberapa indikator penelitian yaitu (Yusrin MN, 2012):

a. Keberanian siswa dalam mengajukan pertanyaan.

b. Mengerjakan soal ke depan kelas.

c. Keberanian menjawab pertanyaan guru.

d. Keberanian menanggapi jawaban siswa lain.

Hasil penelitian pada anak sekolah dasar di studio musik Purwacaraka Surakarta menunjukkan bahwa bermain musik klasik dapat berpengaruh terhadap peningkatan prestasi belajar siswa. Bermain musik klasik dapat membuat siswa lebih cerdas dimana hasil penelitian menunjukkan kenaikan dari nilai uji $\mathrm{T}$ secara statistik dari nilai 83,87 menjadi 85,74 . Hal ini disebabkan karena musik klasik mengandung komposisi nada yang memberikan ketenangan, kenyamanan dan ketentraman dalam konsentrasi belajar (Wieminaty AF, 2012).

Berdasarkan hasil penelitian tentang minat pada lagu bahasa Inggris terhadap kemahiran mendengarkan siswa di SMA Kristen Irene Manado, dapat disimpulkan bahwa ada hubungan yang signifikan antara minat pada lagu bahasa Inggris dengan kemahiran mendengarkan. Semakin tinggi minat pada lagu bahasa Inggris, semakin tinggi kemahiran mendengarkan. Besar pengaruh minat pada lagu bahasa Inggris terhadap kemahiran mendengarkan adalah 71,1\% dengan tingkat kepercayaan 99\% (Angmalisang HY, 2013).

Hasil penelitian menunjukkan bahwa terdapat pengaruh media musik instrumental terhadap keterampilan menulis puisi siswa kelas V SDN Ketintang I/409 Surabaya. Berdasarkan hasil tersebut, pembelajaran menggunakan media musik instrumental sangat baik untuk mendukung kegiatan pembelajaran menulis puisi. Berdasarkan hasil penelitian tersebut maka sebaiknya guru menggunakan media musik instrumental dalam pembelajaran menulis puisi. Hal tersebut sudah terbukti memiliki pengaruh yang signifikan terhadap keterampilan menulis puisi siswa karena dengan media musik instrumental akan membantu siswa menuangkan ide atau gagasannya dalam bentuk puisi (Putri EN, Sukartiningsih W, 2014). 
Terapi musik yang diterapkan pada mahasiswa program studi Ilmu Keperawatan Sekolah Tinggi Ilmu Kesehatan Insan Cendekia Husada Bojonegoro yang sedang menghadapi skripsi menunjukkan pengaruh terhadap tingkat stress mahasiswa. Responden sebanyak 42 mahasiswa yang diberi perlakuan mengalami penurunan tingkat stress sejumlah 27 orang $(64,29 \%)$. Data penelitian juga menunjukkan bahwa 7 mahasiswa $(16,67 \%)$ mengalami tingkat stress yang berat sebelum mendapat perlakuan terapi musik (Ferawati, Amiyakun S, 2015).

Hasil penelitian menunjukkan bahwa, dapat disimpulkan bahwa siswa siswi dengan menggunakan media musik Melayu Modern lebih berpengaruh positif dibandingkan hasil Puisi siswa tanpa menggunakan media musik Melayu Modern. Pada hasil tes keterampilan menulis Puisi sebelum menggunakan $m$ media musik Melayu Modern (pretest) termasuk kategori kurang dengan nilai rata-rata 52,18. Pada hasil menulis Puisi setelah menggunakan media musik Melayu Modern (posttest) terlihat lebih meningkat yakni termasuk kategori baik dengan nilai ratarata 80,45 (Sargiran, 2015).

\section{Peran Lagu Tradisional}

Hasil kajian alat bantu pembelajaran tarian, rumah adat dan lagu daerah dengan pendekatan problem based learning untuk mendukung pembelajaran IPS diperoleh bahwa alat bantu pembelajaran tersebut dapat memudahkan dan percepatan pemahaman siswa. Hasil penelitian dengan menggunakan media pembelajaran dapat dilihat dari nilai rerata pre test dan post test, untuk hasil awal (pre test) adalah 61,33 dan hasil akhir dengan bantuan media pembelajaran (post test) adalah 92,67. Dari hasil penelitian ini menunjukkan bahwa dengan media pembelajaran dapat meningkatkan pemahaman siswa dalam menerima materi, khususnya materi tarian, rumah adat dan lagu daerah (Yuliana, Aliyanto A, 2012).

Kecerdasan musikal siswa dapat ditingkatkan melalui gerak dan lagu menggunakan lagu dolanan tradisional Jawa pada anak kelompok bermain B PAUD Aisyiyah Gantiwarno Klaten. Hal ini terbukti dengan adanya peningkatan persentase kecerdasan musikal anak pada siklus I 59,06\% menjadi $83,12 \%$ pada siklus II. Sehingga dapat disimpulkan bahwa gerak dan lagu menggunakan lagu dolanan tradisional Jawa merupakan media yang efektif untuk meningkatkan kecerdasan musikal anak. Keberhasilan pembelajaran dengan menggunakan gerak dan lagu menggunakan lagu dolanan tradisional Jawa memberikan beberapa implikasi sebagai berikut (Trimulyani R, 2013)):

1. Pentingnya metode dan media pembelajaran yang sesuai dengan kebutuhan anak dan situasi yang dihadapi guru dalam pembelajaran serta menarik minat anak untuk mengikuti kegiatan pembelajaran.

2. Gerak dan lagu menggunakan lagu dolanan tradisional Jawa dapat digunakan untuk meningkatkan kecerdasan musikal anak usia dini.
3. Guru harus berperan aktif dalam proses pembelajaran dengan memotivasi anak dan menjadi fasilitator dalam kegiatan pembelajaran.

Hasil penelitian bentuk dan fungsi simbolis tembang dolanan Jawa menunjukkan bahwa bisa disarankan untuk memberikan kontribusi kepada pengajar bahasa Jawa atau bahasa Indonesia dalam rangka memanfaatkan bentukbentuk tradisi lisan atau sastra lisan, folklor Nusantara, dan pengembangan teori yang terkait dengan itu serta kontribusi praktis bagi pengguna baik anak-anak, keluarga, maupun masyarakat untuk mengembang-kan kebijakan terkait dengan pertahanan nasional, pengembangan industri kreatif, maupun kearifan lokal (Yunita LS, 2014).

Hasil penelitian revitalisasi lagu dolanan anak dalam pembentukan karakter anak usia dini menunjukkan bahwa lagu dolanan anak dapat dijadikan sebagai alat pendidik. Hal ini dapat dilakukan dengan waktu dan tempat kapan saja.

Lagu dolanan anak dapat dikelompokkan menjadi 3 (tiga) yaitu pengetahuan, nasihat atau penanaman sikap, dan keterampilan fisik. Ini sesuai dengan pembagian dalam taksonomi Bloom tentang ranah pendidikan knowledge, affective, dan psychomotor (Hartiningsih S, 2015). Lagu dolanan anak juga sarat dengan pendidikan moral dan sosial, oleh karena itu dolanan anak sangat penting untuk dikenalkan pada anak usia dini yaitu usia pra sekolah dan usia sekolah. Melalui lagu dolanan anak dapat dibentuk karakter yang seutuhnya. Dalam lirik lagu dolanan anak, banyak bercerita tentang cinta kasih pada sesama, kepada Tuhan, pada ayah ibu, keindahan alam, binatang, kebesaran Tuhan yang ditulis dengan bahasa yang sederhana sesuai dengan usia anak-anak, berisi hal-hal yang selaras dengan keadaan anak serta lirik dalam lagu dolanan menyiratkan makna kebersamaan, kemandirian, tanggung jawab, dan nilai-nilai sosial lainnya.

\section{KESIMPULAN DAN SARAN}

Suasana belajar di dalam suatu kelas sangat berpengaruh terhadap hasil proses pembelajaran yang dilakukan. Hasil-hasil penelitian menyatakan bahwa beberapa jenis musik berpengaruh terhadap suasana belajar siswa di dalam kelas. Jenis musik klasik merupakan jenis musik yang banyak diteliti. Musik diapliaksikan sebagai latar belakang suasana belajar dalam kelas. Peranan atau pengaruh musik terhadap suasana belajar dan proses pembelajaran masih berpotensi untuk menjadi obyek penelitian. Hal ini dapat dilakukan untuk jenis-jenis musik yang lain, misalkan musik daerah atau jenis musik yang digemari para siswa. Selain itu dapat juga dilakukan aplikasi lagu daerah atau tradisional untuk proses pembelajaran.

\section{DAFTAR PUSTAKA}

Angmalisang HY, 2013, Pengaruh Minat pada Lagu Bahasa Inggris Terhadap Kemahiran Mendengarkan Siswa di SMA Kristen Irene Manado, Jurusan Sastra Inggris, Fakultas Sastra, Universitas Sam Ratulangi, Manado 
Anwar S, 2013, Pengaruh Musik Terhadap Kesehatan, Jiwa, Fungsi dan Kerja Otak Manusia, http:mahasiswa.ung.ac.id, diakses 30 Juli 2016

Ashari A, Ismet F, Darman D, 2014, Hubungan Suasana Lingkungan Belajar Dalam Kelas Dengan Hasil Belajar Siswa Pada Mata Diklat Sistem Motor Kelas XI Teknik Kendaraan Ringan SMK Adzkia Padang, Abstrak, Automotive Engineering Education Journal, Tim Pengelola e-Journal Jurusan Teknik Otomotif FT UNP

Ekayana AAG, Suharsono N, Tegeh IM, 2013, Pengembangan Perangkat Pembelajaran Mikrokontroler Berbasis Advance Virtual Risc (AVR) Dalam Mata Pelajaran Teknik Mikrokontroler, Journal Program Pascasarjana Universitas Pendidikan Ganesha Program Studi Teknologi Pembelajaran (Volume 3 Tahun 2013)

Ferawati, Amiyakun S, 2015, Pengaruh Pemberian Terapi Musik Terhadap Penurunan Kecemasan dan Tingkat Stress Mahasiswa Semester VII Ilmu Keperawatan Dalam Menghadapi Skripsi di Sekolah Tinggi Ilmu Kesehatan Insan Cendekia Husada Bojonegoro, JUMAKiA 1(1): 1-9

Hartiningsih S, 2015, Revitalisasi Lagu Dolanan Anak Dalam Pembentukan Karakter Anak Usia Dini, Atavisme 18(2): 247-259

Kurniawati LD, Ghozali I, Wartiningsih A, 2013, Pengaruh Musik Klasik Karya WA Mozart Terhadap Kecerdasan Emosional Kelas 5 SDN 06 Pontianak, Program Studi Pendidikan Seni Tari dan Musik FKIP Untan

Marchita Y, 2013, Hubungan Minat pada Musik dengan Motivasi Belajar Mahasiswa, http:yulitamarchita.blogspot.co.id, diakses $30 \mathrm{Juli}$ 2016

Mubarok S, 2013, Pengaruh Musik Klasik pada Janin Dalam Kandungan, http://www.keperawatanprofesionalislami.blogspot.com, diakses 30 Juli 2016

Prajnamita, 2010, Pengaruh Musik Terhadap Kecerdasan Otak, http:prajnamitamanindhya.blogspot.co.id, diakses 30 Juli 2016

Puspitasari DB, 2012, Hubungan Antara Persepsi Terhadap Iklim Kelas dengan Motivasi Belajar Siswa SMP Negeri 1 Bancak, Jurnal Empathy 1(1): 59-67

Putri EN, Sukartiningsih W, 2014, Pengaruh Media Musik Instrumental Terhadap Keterampilan Menulis Puisi, JPGSD 02(02): 1-11

Rismi U, 2012, Musik dan Kecerdasan, http:utarirismi140192.blogspot.co.id, diakses 30 Juli 2016

Sabil H, Winarni S, 2013, Meningkatkan Hasil Belajar Matematika Siswa pada Materi Persamaan Kuadrat Dengan Metode Belajar Aktif Tipe Quiz Team Di Kelas IX SMPN 24 Kota Jambi, Jurnal Edumatica 3(2): 53-57 Salim D, 2010, Pengaruh Musik Terhadap Konsentrasi Belajar Siswa Kelas 2 SMUK 1 Salatiga, Jurnal Musik 2(1): 23-32

Sargiran, 2015, Pengaruh Media Musik Melayu Modern Terhadap Keterampilan Menulis Puisi Siswa Kelas XI IPA Sekolah Menengah Atas Negeri 5 Tanjungpinang Tahun Pelajaran 2014/2015, Artikel E-Journal, Jurusan Pendidikan Bahasa dan Sastra Indonesia, Fakultas Keguruan dan Ilmu Pendidikan, Universitas Maritim Raja Ali Haji, Tanjungpinang

Susanti DW, Rohmah FA, 2011, Efektivitas Musik Klasik Dalam Menurunkan Kecemasan Matematika (Math Anxiety) Pada Siswa Kelas XI, Jurnal Humanitas VIII(2): 129-142

Trimulyani R, 2013, Peningkatan Kecerdasan Musikal Melalui Gerak dan Lagu Menggunakan Lagu Dolanan Tradisional Jawa pada Anak Kelompok Bermain B Paud 'Aisyiyah Gantiwarno Klaten 2012/2013, Fakultas Keguruan dan Ilmu Pendidikan, Universitas Muhammadiyah, Surakarta

Tsuchiya N, Adolphs R. Emotion and Consciousness. Trends in Cognitive Sciences 2007; 11:158-167

Wieminaty AF, 2012, Pengaruh Belajar Musik Klasik Terhadap Peningkatan Prestasi Belajar pada Anak Sekolah Dasar di Studio Musik Purwacaraka Surakarta, Karya Tulis Ilmiah, Program Studi D IV Bidan Pendidik Fakultas Kedokteran, Universitas Sebelas Maret, Surakarta

Wulandini IF, 2011, Pengaruh Media Ilustrasi Musik Terhadap Kemampuan Menulis Puisi Siswa Kelas X: Eksperimen di SMA PGRI 22 Serpong, Abstrak, Fakultas Tarbiyah dan Ilmu Keguruan, UIN Syarif Hidayatullah Jakarta

Yogasara T, Siswanto D, Fransiscus H, Catharina, 2014, Pengaruh Jenis Musik dan Aroma Terapi Terhadap Kemampuan Kognitif
Mahasiswa Untuk Tiap Tipe Kepribadian, Lembaga Penelitian dan Pengabdian kepada Masyarakat, Universitas Katolik Parahyangan

Yuliana, Aliyanto A, 2012, Alat Bantu Pembelajaran Tarian, Rumah Adat dan Lagu Daerah Dengan Pendekatan Problem Based Learning Untuk Mendukung Pembelajaran IPS, Seminar Nasional Teknologi Informasi dan Komunikasi Terapan 2012 (Semantik 2012): 617 621

Yunita LS, 2014, Bentuk dan Fungsi Simbolis Tembang Dolanan Jawa, Nosi 2(5): 472-478

Yusrin MN, 2012, Peningkatan Aktivitas Belajar Siswa Melalui Musik Sebagai Media Pembelajaran Matematika yang Menyenangkan (PTK di Kelas VIII Semester Ganjil SMP Negeri 1 Sambi Tahun Ajaran 2012), Naskah Publikasi, Fakultas Keguruan dan Ilmu Pendidikan, Universitas Muhammadiyah Surakarta 